\title{
PENGARUH KUALITAS PRODUK TERHADAP KEPUASAN PELANGGAN SEMEN BATURAJA DI PALEMBANG PADA PT SEMEN BATURAJA (PERSERO) TbK
}

\author{
Hamid Halin \\ Program Studi Manajemen Universitas Indo Global Mandiri \\ Email : hamidhalin@uigm.ac.id
}

\begin{abstract}
ABSTRAK
Bersamaan dengan perkembangannya, perusahaan industri dituntut untuk bersaing dengan sesama perusahaan sejenis agar dapat menciptakan produk dengan spesifikasi terbaik untuk kepuasan pelanggan yang terpenuhi. Penelitian ini bertujuan untuk mengetahui dan menguji pengaruh kualitas produk terhadap kepuasan pelanggan semen Baturaja di Palembang pada PT. Semen Baturaja (Persero) Tbk, menggunakan metode kuantitatif penelitian statistik dan teknik analisis data yang digunakan adalah analisis regresi linier sederhana. Populasi dalam penelitian ini adalah konsumen bisnis yang menjadi mitra bisnis PT. Semen Baturaja (Persero) Tbk di Palembang dan sampel adalah 78 responden yang diambil dengan menggunakan teknik accidental sampling. Hasil uji validitas instrumen menunjukkan bahwa $\mathrm{r}$ hitung $\geq \mathrm{r}$ tabel artinya semua pernyataan item valid dan reliabilitas di atas 0,70 yang berarti reliabel. Jika dilihat berdasarkan uji t, menunjukkan bahwa nilai t hitung adalah $(5,232) \geq \mathrm{t}$ tabel $(1,665)$ sig $(0,000) \leq 0,05$. Ini menunjukkan bahwa kualitas produk sebagian dipengaruhi kepuasan pelanggan. Dari hasil korelasi, menunjukkan bahwa hubungan antara kualitas produk dan kepuasan pelanggan dengan asumsi moderat yaitu 51,5\%. Kemudian, koefisien determinasi (R2) adalah 0,265 atau 26,5\% dari kualitas produk pada kepuasan pelanggan, sedangkan sisanya $73,5 \%$ dipengaruhi oleh variabel lain yang tidak diteliti dalam penelitian ini.
\end{abstract}

Keywords : Kualitas Produk, Pelanggan, Kepuasaan, Sement Baturaja

\section{Pendahuluan Latar Belakang}

Persaingan dalam suatu Industri merupakan suatu hal yang menjadi perhatian tersendiri bagi para pelaku industri. Perkembangan ilmu pengetahuan dan kemajuan teknologi membuat dunia industri semakin maju dan cepat berkembang. Salah satu Industri yang terus mengalami kemajuan di Indonesia ialah industri semen. Industri semen di Indonesia terus-menerus meningkatkan kualitas baik dari sisi produk, kapasitas produksi, pelayanan, dan pemasaran. Hal ini berakibatkan ragam pilihan bagi konsumen dan konsumen juga menjadi lebih selektif dalam memilih produk mana yang berkualitas tinggi untuk digunakan atau dikonsumsi. Para produsen pun selaku pencipta barang atau jasa akan berusaha memuaskan konsumen dengan berbagai macam produk yang baru dengan inovasi mutakhir agar konsumen tetap menggunakan produk tersebut.
Semen merupakan suatu produk yang sangat dibutuhkan dalam pembangunan infrastruktur, oleh karena itu dibutuhkan semen yang berkualitas baik. Hal ini memungkinkan produsen untuk memproduksi semen yang sesuai dengan keinginan dan kebutuhan konsumen agar konsumen terpuaskan. Meningkatkan kualitas produk untuk memuaskan pelanggan merupakan salah satu hal yang menjadi tujuan bagi setiap perusahaan terlebih perusahaan industri. Banyak produk yang dihasilkan dengan berbagai macam jenis, mutu, serta bentuk, dimana keseluruhan tersebut ditujukan untuk menarik minat pelanggan, sehingga konsumen cenderung akan melakukan aktivitas membeli produk tersebut. Oleh karena itu perusahaan dituntut agar mampu menciptakan produk dengan spesifikasi yang terbaik agar kepuasan pelanggan terpenuhi. Usaha menciptakan dan mempertahankan pelanggan hendaknya 
menjadi prioritas utama bagi perusahaan. Strategi yang tepat dapat menarik pelanggan hendaknya disusun secara cermat, agar pelanggan mau membeli produk yang dihasilkan perusahaan. Lebih dari itu dengan segala kiatnya perusahaan juga harus berupaya agar pelanggan dapat menjadi setia terhadap produk tersebut.

Produk adalah elemen kunci dalam keseluruhan penawaran pasar [1]. Arti dari kualitas produk adalah kemampuan sebuah produk dalam memperagakan fungsinya, hal itu termasuk keseluruhan durabilitas, reabilitas, ketepatan, kemudahan, pengoperasian dan reparasi produk juga atribut lainnya [6]. Kualitas produk merupakan kemampuan produk didalam menjalankan fungsinya dan kualitas produk dapat di ukur melalui pendapat konsumen tentang kualitas itu sendiri, sehingga selera pribadi sangat mempengaruhi. Kualitas itu sendiri sering di anggap sebagai ukuran relatif kebaikan suatu produk atau jasa. Nilai subyektifitas dari seseorang menyebabkan adanya perbedaan dalam memberikan pengertian kualitas.

Dalam kaitannya dengan kepuasan pelanggan, kualitas produk memiliki beberapa dimensi pokok, tergantung pada konteksnya. Dalam kualitas produk ada beberapa dimensi utama yang biasanya digunakan, yaitu kinerja, daya tahan, kesesuaian dengan spesifikasi, reliabilitas, estetika, kesan kualitas, serviceability [14].. Kualitas produk yang dirasakan pelanggan akan menentukan suatu persepsi terhadap kinerja perusahaan, yang pada gilirannya akan berpengaruh pada kepuasan pelanggan. Hal ini lah yang menjadi dasar pemikiran untuk tetap memenuhi kebutuhan, keinginan dan harapan konsumen dalam segala perubahan sehingga tidak akan berpaling ke produk subtitusi.

PT. Semen Baturaja (Persero) Tbk adalah salah satu semen yang berkualitas. Perusahaan ini didirikan tahun 1974 dan terus berupaya meningkatkan jumlah produksi semen dengan melakukan pengembangan kapasitas produksi pabrik dan membangun pabrik baru. Dengan berjalannya program perusahaan untuk meningkatkan produksi, pihaknya optimistis target produksi yang ditetapkan sebesar 3,85 juta ton semen per tahun pada 2017 bisa di wujudkan, menurut Kepala Bagian Humas PT. Semen Baturaja Sahadi di Palembang, peningkatan produksi semen tersebut dilakukan untuk memenuhi kebutuhan masyarakat di Provinsi Sumatra Selatan, Lampung dan beberapa provinsi terdekat lainnya.

Melalui kegiatan optimalisasi pabrik tersebut, produksi PT.Semen Baturaja (Persero) Tbk, saat ini bisa di tingkatkan dengan total kapasitas produksi mencapai 2 juta ton semen per tahun. Jika proyek pengembangan dan pembangunan pabrik baru yang sedang dipersiapkan sekarang ini sesuai dengan rencana, target produksi semen yang ditetapkan pada 2017 sebesar 3,85 juta ton per tahun optimistis bisa di wujudkan.

Adapun kompetitor semen Baturaja dalam memuaskan konsumen dan juga untuk menjaga persaingan didalam pasar sebagai berikut :

\section{Tabel 1}

\section{Kompetitor Semen Baturaja}

\begin{tabular}{|c|l|l|}
\hline No & \multicolumn{1}{|c|}{ Kompetitor } & Kapasitas Produksi \\
\hline \multicolumn{2}{|c|}{ PT. Indocement } \\
1. & & 24,9 juta ton / tahun \\
& Tunggal Prakasa, Tbk & \\
2. & PT. Holcim Indonesia & 12,5 juta ton / tahun \\
3. & PT. Semen Bosowa & 7,2 juta ton / tahun \\
4. & PT. Semen Padang & 6 juta ton / tahun \\
5. & PT. Semen Tonasa & 5,98 juta ton / tahun \\
\hline
\end{tabular}

Sumber :

http://www.kemenprin.go.id/pasokansemen-nasional

Dengan hasil produk yang variatif, konsumen dapat memilih produk yang dapat disesuaikan dengan keadaan lingkungan dan kebutuhan penggunaan. Diantara kekuatan semen Baturaja adalah menghasilkan aplikasi beton yang kuat, 
tahan didaerah yang berkadar sulfat sedang, dapat digunakan didaerah yang bersulfat tinggi, tidak mudah terkelupas, dan retak saat digunakan sebagai acian. Hal ini diperkuat dengan diraihnya Standard Nasional Indonesia (SNI), American Standard (ASTM), European Standard (EN).

Dalam hal ini konsumen sebagai salah satu tolak ukur bagi produsen untuk melihat tingkat kualitas dari produk yang diproduksi, sehingga dibutuhkan kejelian dari produsen untuk melihat tingkat kepuasan konsumen demi menjaga persaingan pasar dengan produsen lain. akan tercipta kepercayaan konsumen terhadap produk yang diproduksi. Oleh karena itu PT. Semen Baturaja (Persero) Tbk selalu berupaya agar pelanggannya tetap setia dengan memfokuskan hal tersebut pada kualitas mengingat masih terdapat keluhan-keluhan dari pelanggan mengenai terdapat barangnya tidak sempurna atau cacat, untuk mengatasinya perusahaan meningkatkan kualitas produk agar mencapai harapan pelanggan dan merasa puas akan barang yang telah dibelinya.

Dari penjelasan permasalahan diatas, maka penulis tertarik untuk mengangkat masalah tersebut dengan judul penelitian ini yaitu "Pengaruh Kualitas Produk Terhadap Kepuasan Pelanggan Semen Baturaja DI Palembang Pada PT. Semen Baturaja (Persero) Tbk"

\section{Perumusan Masalah}

Atas dasar latar belakang dan pembahasan masalah, maka perumusan masalah penelitian dirumuskan sebagai berikut: Apakah terdapat pengaruh kualitas produk semen Baturaja terhadap kepuasan pelanggan?

\section{Tujuan Penelitian}

Untuk mengetahui apakah terdapat pengaruh kualitas produk semen Baturaja terhadap kepuasan pelanggan?

\section{Tinjauan Pustaka Pemasaran}

Menurut American Marketing Association, pemasaran adalah suatu fungsi organisasi dan seperangkat proses untuk menciptakan, mengkomunikasikan, dan menyerahkan nilai kepada pelanggan, dan mengelola hubungan pelanggan dengan cara yang menguntungkan organisasi dan para pemilik sahamnya.

Pemasaran sebagai kegiatan manusia yang diarahkan untuk memenuhi dan memuaskan kebutuhan dan keinginan melalui proses pertukaran [3].

Mendefinisikan pemasaran adalah suatu fungsi organisasi dan sekumpulan proses untuk menciptakan, mengkomunikasikan dan menyampaikan nilai kepada pelanggan serta mengelola hubungan dengan pelanggan yang kesemuanya dapat memberikan manfaat bagi organisasi dan para stakeholder-nya [7].

\section{Pengertian Kualitas Produk}

Arti dari kualitas produk adalah kemampuan sebuah produk dalam memperagakan fungsinya, hal ini termasuk keseluruhan durabilitas, reliabilitas, ketepatan, kemudahan pengoperasian, dan reparasi produk juga atribut produk lainnya [6].

Pengertian produk (product) adalah sesuatu yang dapat ditawarkan kepasar untuk mendapatkan perhatian, dibeli, digunakan, atau dikonsumsi yang dapat memuaskan keinginan atau kebutuhan [5].

Dari beberapa definisi diatas dapat diketahui bahwa produk merupakan elemen penting dalam sebuah perusahaan yang nantinya akan dipergunakan perusahaan sebagai alat pertukaran dengan konsumen yang bisa dimiliki dan dikonsumsi, baik itu produk berwujud maupun produk tidak berwujud agar kebutuhan dan keinginan konsumen dapat terpenuhi.

\section{Dimensi Kualitas Produk}

Kualitas mencerminkan semua dimensi penawaran produk yang menghasilkan manfaat (benefits) bagi pelanggan [14]. 
Kualitas suatu produk baik berupa barang atau jasa ditentukan melalui dimensidimensinya. Dimensi kualitas produk adalah:

a. Performance (kinerja), berhubungan dengan karakteristik operasi dasar dari sebuah produk.

b. Durability (daya tahan), yang berarti berapa lama atau umur produk yang bersangkutan bertahan sebelum produk tersebut harus diganti. Semakin besar frekuensi pemakaian konsumen terhadap produk maka semakin besar pula daya tahan produk.

c. Conformance to specifications (kesesuaian dengan spesifikasi), yaitu sejauh mana karakteristik operasi dasar dari sebuah produk memenuhi spesifikasi tertentu dari konsumen atau tidak ditemukannya cacat pada produk.

d. Features (fitur), adalah karakteristik produk yang dirancang untuk menyempurnakan fungsi produk atau menambah ketertarikan konsumen terhadap produk.

e. Reliability (reliabilitas), adalah probabilitas bahwa produk akan bekerja dengan memuaskan atau tidak dalam periode waktu tertentu. Semakin kecil kemungkinan terjadinya kerusakan maka produk tersebut dapat diandalkan.

f. Aesthetics (estetika), berhubungan dengan bagaimana penampilan produk.

g. Perceived quality (kesan kualitas), sering dibilang merupakan hasil dari penggunaan pengukuran yang dilakukan secara tidak mengerti atau kekurangan informasi atas produk yang bersangkutan.

h. Serviceability meliputi kecepatan dan kemudahan untuk direparasi, serta kompetensi dan keramah tamahan staf layanan.

\section{Pengertian Kepuasan Pelanggan}

Pengertian dari kepuasan pelanggan adalah perasaan senang atau kecewa seseorang yang muncul setelah membandingkan antara persepsi atau kesan terhadap kinerja atau hasil suatu produk dan harapan-harapannya [5].
Kepuasan pelanggan merupakan pendorong utama bagi retensi dan loyalitas pelanggan. Sebagian pelanggan mendasarkan kepuasannya semata-mata hanya pada dorongan harga, sedangkan kebanyakan pelangan lainnya mendasarkan kepuasannya pada keputusan pembelian atas dasar tingkat kepuasan produk yang mereka butuhkan [3].

Dari penjelasan diatas menunjukkan bahwa kepuasan pelanggan merupakan suatu pemenuhan harapan. Pelanggan dapat dikatakan puas apabila harapan pelanggan akan produk atau jasa yang di dapat telah sesuai bahkan melebihi harapan mereka.

\section{Dimensi Kepuasan Pelanggan}

Setiap dimensi terdiri dari sub-sub dimensi yang dapat dijadikan dasar pijakan untuk mengidentifikasi atribut yang dipertimbangkan dalam suatu penelitian. Tingkat kepuasan konsumen dapat ditentukan berdasar pada faktok utama yang harus diperhatikan oleh sebuah perusahaan [10], yaitu:

a. Kualitas produk

Konsumen akan merasa puas apabila hasil evaluasi mereka menunjukkan bahwa produk yang mereka gunakan berkualitas.

b. Kualitas pelayanan

Konsumen akan merasa puas apabila mereka mendapatkan pelayanan yang sesuai diharapkan terutama untuk industri jasa.

c. Emosional

Konsumen akan merasa bangga dan mendapatkan keyakinan bahwa orang lain akan kagum terhadap konsumen tersebut apabila menggunakan merek tertentu yang cenderung mempunyai tingkat kepuasan.

d. Harga

Produk yang mempunyai kualitas yang sama tetapi menetapkan harga yang relatif murah akan memberikan nilai lebih tinggi kepada konsumennya. 
e. Biaya

Konsumen tidak mengeluarkan biaya tambahan atau tidak perlu membuang waktu untuk mendapatkan suatu produk atau jasa tersebut.

\section{Hubungan Kualitas Produk Terhadap Kepuasan Pelanggan}

Hubungan kualitas produk yang diterapkan oleh perusahaan erat kaitannya dengan kepuasan pelanggan. Kualitas produk yang diberikan perusahaan harus sesuai dengan jenis produk dan kondisi perusahaan, meskipun produk yang dihasilkan oleh perusahaan telah sesuai dengan yang diharapkan konsumen, tetapi tanpa ditunjang dengan kualitas produk baik dan benar maka mengakibatkan ketidakberhasilan dalam memenuhi kepuasan pelanggan. Definisi produk adalah segala sesuatu yang ditawarkan pada sebuah pasar untuk diperhatikan, digunakan, dan diasumsi sehingga dapat memuaskan keinginan/ kebutuhan konsumen [11]. Sekelompok atribut penting dalam suatu produk akan mempengaruhi sikap puas/ ketidakpuasan konsumen terhadap produk atau jasa tertentu. Dengan adanya kualitas yang bagus dan terpercaya, produk akan senantiasa tertanam dibenak konsumen karena konsumen bersedia membayar sejumlah uang untuk membeli produk yang berkualitas [6].

\section{Manfaat Yang di Dapat Perusahaan Bila Mencapai Kepuasan Pelanggan}

Apabila kepuasan pelanggan tercapai akan dapat memberikan beberapa manfaat bagi perusahaan. Manfaat-manfaat yang di dapat [14], adalah :

1. Hubungan antara perusahaan dan para pelanggan menjadi harmonis.

2. Memberikan dasar yang baik bagi pembelian ulang.

3. Dapat mendorong terciptanya loyalitas pelanggan.

4. Membentuk suatu rekomendasi dari mulut ke mulut yang menguntungkan perusahaan.
5. Reputasi perusahaan menjadi baik dimata pelanggan.

6. Laba yang diperoleh meningkat.

\section{Kerangka Pemikiran}

Dalam penelitian ini kerangka pemikiran dapat disederhanakan lagi dalam bentuk gambar 1 di bawah ini

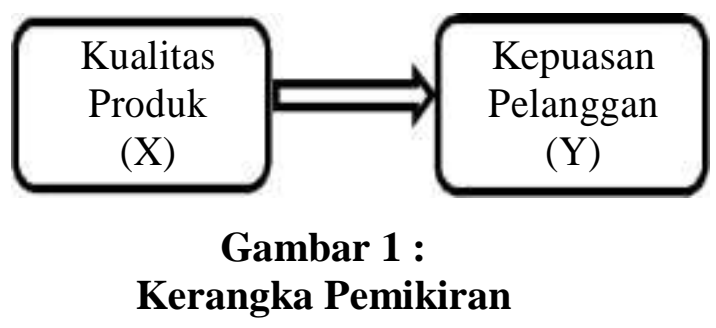

\section{Hipotesis}

Berdasarkan kerangka pemikiran diatas, maka dapat dirumuskan suatu hipotesis yang merupakan dugaan sementara dalam menguji suatu penelitian, yaitu :

$\mathrm{H}_{\mathrm{o}}$ : Kualitas produk tidak berpengaruh signifikan terhadap kepuasan pelanggan semen Baturaja di Palembang.
$\mathrm{H}_{\mathrm{a}}$ : Kualitas produk berpengaruh signifikan terhadap kepuasan pelanggan semen Baturaja di Palembang.

\section{Metodologi Penelitian Jenis dan Sumber Data}

Referensi penelitian tersebut menggunakan dua jenis data yaitu :

a. Data Primer

Data Primer merupakan sumber data yang diperoleh secara langsung oleh peneliti. Data primer dalam penelitian ini dikumpulkan langsung dari lokasi penelitian melalui wawancara dan kuesioner yang diberikan kepada para pelanggan toko yang ditetapkan sebagai responden.

b. Data Sekunder

Data Sekunder diperoleh melalui studi kepustakaan dengan mempelajari literatur, buku, majalah dan 
dokumentasi resmi PT. Semen Baturaja (Persero) Tbk, serta semua sumber yang memungkinkan dan berkaitan termasuk media internet.

\section{Teknik Pengumpulan Data}

Teknik pengumpulan data dalam penelitian ini adalah

a. Studi Kepustakaan (library research) Teknik studi kepustakaan dilakukan untuk mengambil data yang bersifat teori yang kemudian digunakan sebagai literatur penunjang guna mendukung penelitian yang dilakukan. Data ini diperoleh dari buku-buku sumber yang dapat dijadikan acuan yang ada kaitannya dengan masalah yang diteliti.

b. Wawancara (interview)

yaitu cara pengumpulan data yang dilakukan langsung melalui tanya jawab antara penulis dengan petugas yang berwenang yang ada hubungannya dengan masalah yang diteliti.

c. Kuesioner

pengumpulan data dengan menggunakan daftar pernyataan yang digunakan untuk mengetahui persepsi responden terhadap beberapa variabel.

d. Dokumentasi

Dokumentasi dapat dilakukan dengan cara mengumpulkan beberapa fakta yang berhubungan dengan masalah dan tujuan penelitian. Dalam penelitian ini, dokumentasi didapatkan secara langsung dari PT. Semen Baturaja (Persero) Tbk yang terkait dengan data yang menunjang dalam penelitian ini.

\section{Populasi}

Populasi merupakan wilayah generalisasi yang terdiri atas obyek / subyek yang mempunyai kualitas dan karakteristik tertentu yang ditetapkan oleh seorang peneliti untuk dipelajari dan kemudian ditarik sebuah kesimpulannya [12]. Pada langkah awal peneliti harus menentukan secara jelas mengenai populasi sasaran penelitian yang disebut dengan populasi sasaran (target population), yaitu populasi yang nantinya akan menjadi cakupan kesimpulan penelitian.

Berdasarkan paparan diatas maka populasi dalam penelitian ini adalah konsumen bisnis yang menjadi mitra usaha PT. Semen Baturaja (Persero) Tbk, di kota Palembang yang berjumlah 348 toko berdasarkan hasil wawancara dengan pihak PT. Semen Baturaja (Persero) Tbk, bagian Biro Pemasaran di Palembang.

Alasan peneliti memilih toko sebagai customer adalah toko merupakan konsumen yang membeli semen Baturaja langsung pada distributor yang ada di Kota Palembang atau yang biasa disebut konsumen akhir dan toko diharapkan dapat mewakili suara konsumen semen Baturaja.

\section{Sampel}

Sampel sebagian dari jumlah dan karakteristik yang dimiliki oleh populasi tersebut [12]. Untuk menentukan sampel dari populasi yang telah ditetapkan, perlu dilakukan suatu pengukuran yang menghasilkan jumlah $n$. dalam penelitian ini menggunakan teknik Slovin, dengan rumus sebagai berikut :

$$
n=\frac{N}{1+N(e)^{2}}
$$

Keterangan :

$$
\begin{aligned}
n= & \text { Jumlah sampel } \\
N= & \text { Jumlah populasi } \\
e= & \text { kelonggaran ketidaktelitian karena } \\
& \text { kesalahan sampel yang masih dapat } \\
& \text { ditolerir }(e=0,1)
\end{aligned}
$$

Berdasarkan rumus Slovin tersebut maka jumlah sampel yang diperoleh adalah :

$$
\begin{array}{ll} 
& 348 \\
\mathrm{n} & =77,678 \text { dibulatkan }(\mathrm{n}=78 \\
& \text { responden }) 1+348(0,1)^{2}
\end{array}
$$


Karena jumlah sub populasi tidak sama maka penentuan jumlah sampel tiap-tiap sub populasinya menggunakan teknik pengambilan sampel dengan Stratified Random Sampling yang proportional, yaitu suatu teknik pengambilan sampel secara acak dengan jumlah yang proporsional untuk setiap sub populasi sesuai dengan ukuran populasinya, dengan rumus sebagai berikut :

\section{Populasi x Total Sampel}

Total Populasi

Dari penjelasan diatas maka besar sampel masing-masing responden sejumlah yang disajikan pada tabel 2 di bawah ini :

Tabel 2

Pengambilan Sampel di Kota Palembang Tahun 2017

\begin{tabular}{|l|lcc|}
\hline No & \multicolumn{1}{|c|}{ Kecamatan } & $\begin{array}{l}\text { Populas } \\
\text { i }\end{array}$ & $\begin{array}{l}\text { Sampe } \\
\text { l }\end{array}$ \\
\hline 1. & Kertapati & 24 & 5 \\
2. & Seberang Ulu I & 15 & 3 \\
3. & Seberang Ulu II & 19 & 4 \\
& Alang-Alang & & \\
4. & Lebar & 24 & 5 \\
5. & Sukarami & 25 & 6 \\
6. & Plaju & 26 & 6 \\
7. & Ilir Barat I & 23 & 5 \\
8. & Ilir Barat II & 22 & 5 \\
9. & Ilir Timur I & 19 & 4 \\
10. & Ilir Timur II & 21 & 5 \\
11. & Sematang Borang & 26 & 6 \\
12. & Kalidoni & 26 & 6 \\
13. & Bukit Kecil & 14 & 3 \\
14. & Kemuning & 18 & 4 \\
15. & Sako & 28 & 7 \\
16. & Gandus & 18 & 4 \\
\multicolumn{2}{|l}{ Jumlah Toko } & $\mathbf{3 4 8}$ & $\mathbf{7 8}$ \\
\hline
\end{tabular}

Sumber : PT. Semen Baturaja (Persero)

Tbk

Berhubung penulis tidak menyajikan nama-nama toko yang akan di jadikan responden, maka untuk menentukan responden peneliti menggunakan Teknik Penarikan Sampel Aksidental. Teknik ini didasarkan pada kemudahan (convenience). Sampel dapat dipilih karena berada pada waktu, situasi, dan tempat yang tepat.

\section{Definisi Operasional dan Pengukuran Variabel}

Variabel penelitian terdiri atas dua macam yaitu variabel bebas (independent variabel) atau variabel yang tidak bergantung pada variabel lainnya. Dan variabel terikat (dependent variabel) atau variabel yang tergantung dari variabel lainnya [12].

Variabel-variabel yang digunakan dalam penelitian ini adalah :

1. Variabel tidak terikat (independent), yaitu kualitas produk (X).

2. Variabel terikat (dependent), yaitu kepuasan pelanggan (Y).

Variabel-variabel diatas dapat dilihat lebih jelas dan terperinci yang disajikan dalam tabel 3 operasional variabel berikut ini :

Tabel 3

Operasional Variabel

\begin{tabular}{|ccl|}
\hline Variabel & Dimensi & \multicolumn{1}{c|}{ Indikator } \\
\hline Kualitas & Performance & Fungsi utama produk \\
Produk & & \\
& Durability & Daya tahan produk \\
(X) & & \\
Tjiptono & Conformance & Kesesuaian produk \\
$(2015: 76)$ & Feature & Karakteristik produk \\
& Reliability & Kehandalan Produk \\
& Aesthetic & Kemasan dan \\
& & penampilan produk \\
Kepuasan & Kualitas & Tingkat kepuasan \\
Pelanggan & Produk & konsumen berdasarkan \\
(Y) & & kualitas produk \\
(Irawan, & Harga & Tingkat \\
2007 & & kepuasan \\
dalam & & konsumen berdasarkan \\
Sudaryon & & harga yang ditetapkan \\
o & Biaya & Tingkat \\
2016:82) & & Konsumen berdasarkan
\end{tabular}




\begin{tabular}{|c|c|}
\hline \multirow[b]{2}{*}{ Kemudahan } & $\begin{array}{l}\text { biaya tambahan yang } \\
\text { dikeluarkan }\end{array}$ \\
\hline & $\begin{array}{l}\text { Tingkat kepuasan } \\
\text { konsumen berdasarkan } \\
\text { Kemudahan dalam } \\
\text { memperoleh produk }\end{array}$ \\
\hline Kualitas & Tingkat kepuasan \\
\hline Pelayanan & $\begin{array}{l}\text { konsumen berdasarkan } \\
\text { kualitas pelayanan }\end{array}$ \\
\hline Faktor & Kepuasan konsumen \\
\hline Emosional & $\begin{array}{l}\text { berdasarkan nilai sosial } \\
\text { yang didapatkan }\end{array}$ \\
\hline
\end{tabular}

Sumber : Hasil Olahan

Penulis

Untuk mengukur tanggapan responden terhadap variabel-variabel penelitian dilakukan dengan menggunakan alat dalam bentuk kuesioner yang diisi oleh responden dibuat dalam bentuk pernyataan dimana dalam kuesioner sudah disediakan alternatif jawaban dari item pernyataan.

Untuk mempermudah pengambilan kesimpulan dari tanggapan responden yang diperoleh dalam pembagian kuesioner, maka digunakan skala 5 tingkat (likert). Alternatif jawaban disesuaikan dengan sekala likert yang dibuat menjadi 5 alternatif jawaban. Skala likert melibatkan serangkaian pernyataan yang berkaitan dengan sikap responden diminta menyatakan "Sangat Tidak Setuju (STS)" sampai pada jawaban "Sangat Setuju (SS)" untuk setiap pernyataan, jawaban diberi nilai yang akan merefleksikan secara konsisten sikap responden.

Untuk setiap jawaban akan diberi skor 1-5 yang dapat dijelaskan sebagai berikut:

1. Skor 1 untuk jawaban Sangat Tidak Setuju (STS).

2. Skor 2 untuk jawaban Tidak Setuju (TS).

3. Skor 3 untuk jawaban Netral (N).

4. Skor 4 untuk jawaban Setuju (S).

5. Skor 5 untuk jawaban Sangat Setuju (SS).

Teknik Analisis

Analisis Deskriptif
Analisis ini tidak menggunakan pengujian secara sistematis dan statistik. Dimaksudkan hanya untuk menggambarkan angka-angka responden dari objek penelitian yang diperoleh dari hasil analisis deskriptif.

\section{Uji Validitas Instrumen}

Uji Validitas adalah ketepatan antara data yang terkumpul dengan data yang sesungguhnya terjadi pada obyek yang diteliti. Uji validitas instrument dalam penelitian ini digunakan untuk mengukur sah atau tidaknya suatu kuesioner. Suatu kuesioner dikatakan valid jika pada kuesioner mampu mengungkapkan sesuatu yang akan diukur oleh kuesioner tersebut [12].

Pengujian validitas ini dapat digunakan dengan rumus Korelasi Product Moment, sebagai berikut :

$$
\mathbf{r x y}=\frac{n\left(\sum\right)-\left(\sum\right)\left(\sum\right)}{\left\{_{2}^{2}(\Sigma)-\left(\sum\right)\right\}\left\{\left(\sum\right)-(\Sigma\right.}
$$

Keterangan :

rxy $=$ Koefisien Korelasi antara variabel $\mathrm{X}$ dan Variabel Y

$=$ Koefisien validitas item yang dicari, dua variabel yang dikorelasikan

$\mathrm{X}=$ Skor untuk pernyataan yang dipilih

$\mathrm{Y}=$ Skor total yang diperoleh dari seluruh item

$\sum \mathrm{X}=$ Jumlah skor dalam distribusi $\mathrm{X}$

$\sum \mathrm{Y}=$ Jumlah skor dalam distribusi $\mathrm{Y}$

$\sum X^{2}=$ Jumlah kuadrat dalam skor distribusi X

$\sum \mathrm{Y}^{2}=$ Jumlah kuadrat dalam skor distribusi Y

$\mathrm{N}=$ Banyaknya responden

Penggujian validitas instrumen menggunakan Analyst Correlate Bivariate untuk mecari correlation coefficient dari Product Moment Pearson dengan SPSS versi 15.0. Kemudian dibandinggkan dengan nilai $r_{\text {tabel }}$ untuk $\alpha=0.05$ dengan derajat kebebasan $(\mathrm{dk}=\mathrm{n}-2)$ sehingga 
didapat $\mathrm{r}$ tabel. Untuk butir pernyataan dengan nilai koefisien korelasi ( $\left.\mathrm{r}_{\text {hitung }}\right)>(\mathrm{r}$ tabel) maka butir pernyataan tersebut dinyatakan valid.

\section{Uji Reliabilitas Instrumen}

Setelah instrument di uji validitasnya maka langkah selanjutnya yaitu menguji reliabilitas. "instrument yang reliabel adalah instrument yang bila digunakan beberapa kali untuk mengukur obyek yang sama, akan menghasilkan data yang sama [12]." Pengujian reliabilitas instrument dengan rentang skor 1-5 menggunakan rumus Cronbach's Alpha, dengan rumus sebagai berikut :

$$
r 11=(\quad)(1-\Sigma)
$$

Keterangan :

$$
\begin{array}{ll}
r 11 & =\text { Reliabilitas yang dicari } \\
k & =\text { banyaknya butir pertanyaan } \\
\Sigma & =\text { Jumlah varian butir tiap } \\
& \text { pertanyaan }
\end{array}
$$

$\mathrm{V}=$ Varian total

Keputusan pengujian reliabilitas intrumen sebagai beikut:

1. Instrument dikatakan reliabel jika $r_{\text {hitung }}$ $\geq \mathrm{r}_{\text {tabel }}$.

2. Instrumen dikatakan tidak reliabel jika $r$ hitung $\leq \mathrm{r}$ tabel. Artinya butir kuesioner dikatakan reliabel jika Cronbach's Alpha $\geq 0,70$ dan dikatakan tidak reliabel jika Cronbach's Alpha $\leq 0,70$ [2].

Atau ada pula yang memaknainya sebagai berikut : Jika alpha $\geq 0,90$ maka reliabilitas sempurna.

Jika alpha antara 0,70 - 0,90 maka reliabilitas tinggi. Jika alpha 0,50 0,70 maka reliabilitas moderat. Jika alpha $\leq 0,05$ maka reliabilitas rendah.

Jika alpha rendah, kemungkinan satu atau beberapa item tidak reliabel.

\section{Analisis Regresi Sederhana}

Adapun pengolahan data pada penelitian ini dengan menggunakan analisis regresi sederhana (simple regression analysis), dilakukan apabila hubungan dua variabel merupakan hubungan kausal atau fungsional. Analisis regresi digunakan apabila kita ingin mengetahui bagaimana variabel dependen dapat diprediksi melalui variabel independen secara individual. Analisis regresi sederhana adalah suatu teknik analisis yang mempelajari ketergantungan satu variabel tidak bebas hanya pada satu variabel bebas, dengan rumus :

$$
\mathrm{Y}=\alpha+b X
$$

Keterangan:

$$
\begin{aligned}
& \text { Y }=\text { Profitabilitas Net Profit Margin } \\
& X=\text { Perputaran Piutang } \\
& \text { a }=\text { Nilai Konstan Regresi } \\
& \text { b }=\text { Koefisien Regresi }
\end{aligned}
$$

\section{Uji Korelasi}

Analisis ini digunakan untuk memperoleh koefisien korelasi, yaitu ukuran hubungan linear antara dua variabel. Dalam penelitian ini menghitung korelasi menggunakan koefisien Pearson. Koefisien ini menghitung mengukur keeratan hubungan diantara hasil-hasil pengamatan dari populasi yang mempunyai dua varian (bivariate).

Pedoman interprestasi keeratan hubungan antar dua variabel tersebut bisa diliat pada tabel dibawah ini. 
Tabel 4 Interprestasi Koefisien Korelasi

\begin{tabular}{|c|c|}
\hline $\begin{array}{l}\text { Nilai Koefisien } \\
\text { Korelasi }\end{array}$ & Interprestasi \\
\hline $0,1-0,199$ & Sangat Rendah \\
$0,20-0,399$ & Rendah \\
$0,40-0,599$ & Sedang \\
$0,60-0,799$ & Kuat \\
$0,80-1,000$ & Sangat Kuat \\
\hline
\end{tabular}

Sumber : [12].

\section{Uji $\mathbf{R}^{2}$ Koefisien Determinan}

Koefisien determinasi $\left(\mathrm{R}^{2}\right)$ adalah kuadrat koefisien korelasi, dalam penggunaan koefisien determinasi $\left(\mathrm{R}^{2}\right)$ dinyatakan dalam persen sehingga harus dikalikan $100 \%$. Koefisien determinasi $\left(\mathrm{R}^{2}\right)$ ini digunakan untuk mengukur seberapa besar kontribusi variabel bebas terhadap variabel terikat. Jika koefisien determinasi $\left(\mathrm{R}^{2}\right)$ semakin besar (mendekati satu) menunjukkan semakin banyak kemampuan variabel $\mathrm{X}$ menerangkan variabel Y. sebaliknya, jika koefisien determinasi $\left(\mathrm{R}^{2}\right)$ semakin kecil (mendekati nol), maka akan dikatakan bahwa pengaruh variabel bebas adalah kecil terhadap variabel-variabel terikat. Hal ini berarti model yang digunakan tidak kuat untuk menerangkan pengaruh variabel bebas yang diteliti terhadap variabel terikat.

\section{Pengujian Hipotesis}

Yaitu untuk mengetahui pengaruh antara variabel-variabel yang digunakan itu berarti (signifikan) atau tidak. Untuk menguji keberartiannya itu melalui hipotesis dimana :

$\mathrm{H}_{\mathrm{o}}$ : Kualitas produk tidak berpengaruh signifikan terhadap kepuasan pelanggan semen Baturaja di Palembang.

\begin{tabular}{|c|c|c|c|}
\hline $\mathrm{H}_{\mathrm{a}}$ & $\begin{array}{l}\text { Kualitas } \\
\text { signifikan }\end{array}$ & $\begin{array}{l}\text { produk } \\
\text { terhadap }\end{array}$ & $\begin{array}{r}\text { berpengaruh } \\
\text { kepuasan }\end{array}$ \\
\hline & $\begin{array}{l}\text { pelanggan } \\
\text { Palembang. }\end{array}$ & semen & Baturaja di \\
\hline
\end{tabular}

Dengan rumus sebagai berikut :

$$
\text { thitung }=r \frac{(-2)}{\sqrt{1}-}
$$

Dimana :

$$
\begin{aligned}
t & : \text { Statistik uji hipotesa } n: \text { Jumlah } \\
& \text { responden } \\
r & : \text { Koefisien korelasi antar variabel } \\
& \text { kualitas produk }
\end{aligned}
$$

(X) dengan kepuasan pelanggan (Y).

\section{2 : Bilangan konstanta}

Dalam pengujian taraf nyata $(a)$ sebesar 0,05 dengan memiliki derajat kebebasan $(\mathrm{dk})=-2$, dengan kriteria :

Jika $t_{\text {hitung }} \geq \mathrm{t}_{\text {tabel }}$ maka Ho ditolak Jika $\mathrm{t}_{\text {hitung }} \leq \mathrm{t}_{\text {tabel }}$ maka Ho diterima artinya pengujian signifikan.

\section{Hasil Penelitian dan Pembahasan}

\section{Hasil Penelitian}

Pada penelitian ini dilakukan di PT. Semen Baturaja (Persero) Tbk, penulis mengajukan seperangkat kuesioner kepada responden yang berjumlah 78 orang. Kuesioner variabel kualitas produk terdiri dari 10 butir pernyataan dan variabel kepuasan pelanggan terdiri dari 10 butir pernyataan. Setelah data kuesioner telah dikumpulkan selanjutnya perlu di uji validitas dan reliabilitas sebagai persyaratan analisis untuk menentukan valid atau tidak data tersebut.

\section{Uji Validitas Instrumen}

Penggujian validitas instrumen menggunakan Analyst Correlate Bivariate untuk mecari correlation coefficient dari Product Moment Pearson dengan SPSS 15.0. Kemudian dibandingkan dengan nilai $r$ tabel untuk $\alpha=0,05$ dengan derajat kebebasan $(\mathrm{dk}=\mathrm{n}-2)$ sehingga didapat $\mathrm{r}$ tabel. Untuk butir pernyataan dengan nilai koefisien korelasi $\left(\mathrm{r}_{\text {hitung }}\right)>\left(\mathrm{r}_{\text {tabel }}\right)$ maka butir pernyataan tersebut dinyatakan valid. 
Karena jumlah responden yang digunakan untuk uji validitas sebanyak 78 orang, maka nilai $r$ tabel dapat ditentukan dari : $(\mathbf{d k}=\mathbf{n}-\mathbf{2})=\mathbf{7 8}-\mathbf{2}$ $=76$ nilai $\mathrm{r}_{\text {tabel }}$ dengan $\mathrm{dk}=76$ adalah 0,222 . Jadi, jika $r$ hitung $\geq 0,222$ maka item pertanyaan dinyatakan valid.

Berdasarkan perhitungan dengan menggunakan aplikasi SPSS versi 15.0, diketahui hasil uji validitas variabel $X$ dan variabel $\mathrm{Y}$ terlihat bahwa nilai $\mathrm{r}_{\text {hitung }}$ pada kolom corrected item-total correlation untuk masing-masing item memiliki $r_{\text {hitung }}$ $\geq \mathrm{r}_{\text {tabel }}$ untuk (df) $78-2=76$ dan alpha sebesar 5\% dengan uji dua sisi didapat $r$ tabel sebesar 0,222. Artinya semua item pernyataan dari variabel (X) kualitas produk dan variabel (Y) kepuasan Pelanggan adalah valid.

\section{Uji Reliabilitas}

Pada penelitian ini uji reliabilitas menggunakan metode Cronbach Alpha. Reliabilitas diukur dengan menguji tingkat konsistensi hasil pengukuran jika dilakukan pengukuran ulang. Handal atau tidaknya suatu data dapat dilihat dari koefisien alpha yang dihasilkan, data yang melebihi angka 0,90 dapat dikatakan memiliki keandalan sempurna. Suatu data dikatakan akurat jika nilai koefisien Cronbach Alpha $\geq 0,70$. [2]. Uji reliabilitas pada penelitian ini menggunakan program SPSS versi 15.0.

Berdasarkan hasil uji reliabilitas variabel kualitas produk $(\mathrm{X})$ terlihat bahwa nilai Cronbach Alpha yang diperoleh sebesar $0,775 \geq 0,70$, dan hasil uji reliabilitas variabel kepuasan pelanggan (Y) di dapat nilai Cronbach Alpha sebesar $0,748 \geq 0,70$, yang artinya semua keseluruhan item dalam instrument pengukuran dapat di kategorikan reliabilitas tinggi. Dengan demikian pengolahan data dapat dilanjutkan kelangkah selanjutnya.

\section{Analisis Regresi Linier Sederhana}

Analisis regresi ini dilakukan dengan menggunakan metode enter, dimana semua variabel dimasukkan untuk mencari pengaruh variabel independen terhadap variabel dependen.

Dengan demikian, kualitas produk digunakan dalam model penelitian ini untuk menentukan pengaruhnya terhadap kepuasan pelanggan semen Baturaja di Palembang pada PT. Semen Baturaja (Persero) Tbk. Hasil analisa regresi dengan menggunakan metode enter dapat dilihat pada tabel berikut:

\section{Tabel 5}

\section{Hasil Analisis Regresi Sederhana}

\section{Coefficients $^{\mathrm{a}}$}

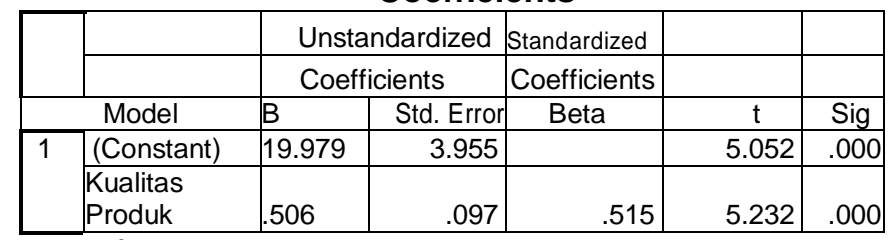

a. Dependent Variable: Kepuasan Pelanggan

Sumber : Hasil Olahan Data SPSS 15.0

Berdasarkan hasil analisis data yang dilakukan dengan menggunakan bantuan SPSS 15.0 menunjukkan bahwa persamaan regresi linier sederhana sebagai berikut :

$\mathrm{Y}=\mathrm{a}+\mathrm{bX}$

$\mathrm{Y}=19,979+(0,506) \mathrm{X}$, maka:

Kepuasan Pelanggan $=19,979+0,506 \mathrm{X}$ Persamaan regresi diatas dapat diartikan sebagai berikut:

1. Koefisien konstanta sebesar 19,979 menyatakan bahwa jika $X$ adalah bernilai nol (0). Artinya adalah apabila kualitas produk bernilai nol (0), maka Kepuasan Pelanggan bernilai sebesar 19,979

2. Koefisien regresi untuk variabel Kualitas Produk sebesar 0,506. Artinya adalah menunjukkan bahwa setiap peningkatan variabel Kualitas Produk sebesar 1 point maka akan menaikkan nilai Kepuasan Pelanggan sebesar 0,506 
dengan asumsi variabel lain bernilai tetap.

\section{Uji Korelasi}

Uji $\mathrm{R}$ menunjukkan korelasi berganda yaitu korelasi antara dua atau lebih variabel independen terhadap variabel dependen. Koefisien korelasi dikatakan kuat jika nilai $\mathrm{R}$ berada diatas 0 sampai 1 , jika nilainya mendekati 1 , maka hubungan semakin erat. Hasil analisa korelasi dengan menggunakan metode enter dapat dilihat pada tabel berikut:

\section{Tabel 6}

\section{Hasil Analisis Uji Korelasi}

Model Summary

\begin{tabular}{|l|r|r|r|c|}
\hline Model & \multicolumn{1}{|c|}{ R } & R Square & $\begin{array}{l}\text { Adjusted } \\
\text { R Square }\end{array}$ & $\begin{array}{c}\text { Std. Error of } \\
\text { the Estimate }\end{array}$ \\
\hline 1 & $.515^{\mathrm{a}}$ & .265 & .255 & 3.334 \\
\hline
\end{tabular}

a. Predictors: (Constant), Kualitas Produk

Sumber : Hasil Olahan Data SPSS 15.0

Dari tabel diatas menunjukkan bahwa besarnya nilai korelasi / hubungan (R) yaitu sebesar $=0,515$ yang berarti bahwa hubungan antara Kualitas Produk terhadap Kepuasan Pelanggan berasumsi sedang yaitu sebesar $51,5 \%$.

\section{Uji $\mathbf{R}^{2}$ Koefisien Determinasi}

Koefisien determinasi $\left(\mathrm{R}^{2}\right)$ ini digunakan untuk mengukur seberapa besar kontribusi variabel bebas terhadap variabel terikat. Jika koefisien determinasi $\left(\mathrm{R}^{2}\right)$ semakin besar (mendekati satu) menunjukkan semakin banyak kemampuan variabel $\mathrm{X}$ menerangkan variabel Y. Sebaliknya, jika koefisien determinasi $\left(\mathrm{R}^{2}\right)$ semakin kecil (mendekati nol), maka akan dikatakan bahwa pengaruh variabel bebas adalah kecil terhadap variabel-variabel terikat.

dengan asumsi :

$$
\begin{aligned}
& K P=r^{2} \times 100 \% \\
& K P=\text { Nilai Koefisien } \\
& \text { Determinasi }
\end{aligned}
$$

\section{$r=$ Nilai Koefisien \\ Korelasi}

Hasil uji $\mathrm{R}^{2}$ koefisien determinasi dapat di lihat pada tabel di bawah ini :

Tabel 7

\section{Hasil Analisis Uji $\mathbf{R}^{2}$ Koefisien Determinasi}

\section{Model Summary}

\begin{tabular}{|l|c|r|r|r|}
\hline Model & $\mathrm{R}$ & $\mathrm{R}$ Square & $\begin{array}{c}\text { Adjusted } \\
\text { R Square }\end{array}$ & $\begin{array}{r}\text { Std. Error of } \\
\text { the Estimate }\end{array}$ \\
\hline 1 & $.515^{\mathrm{a}}$ & .265 & .255 & 3.334 \\
\hline \multicolumn{4}{|c|}{ a. Predictors: (Constant), Kualitas Produk } \\
\hline
\end{tabular}

Sumber : Hasil Olahan Data SPSS 15.0

Dari tabel diatas dapat dijelaskan besarnya presentase pengaruh variabel bebas terhadap variabel terikat yang disebut koefisien determinasi yang merupakan hasil dari penguadratan R. dari output tersebut diperoleh koefisien determinasi $\left(\mathrm{R}^{2}\right)$ sebesar 0,265, yang mengandung pengertian bahwa pengaruh variabel bebas (Kualitas Produk) terhadap variabel terikat (Kepuasan Pelanggan) adalah sebesar $26,5 \%$, sedangkan sisanya yaitu $73,5 \%$ (100\% - 26,5\%) dipengaruhi oleh variabel lain yang tidak diteliti dalam penelitian ini.

\section{Hipotesis}

Uji $t$ digunakan untuk menguji signifikansi konstanta dengan tujuan untuk mengukur pengaruh Kualitas Produk secara parsial terhadap Kepuasan Pelanggan.

- $\quad$ Hipotesis

$\mathrm{H}_{\mathrm{o}}$ : Kualitas produk tidak berpengaruh signifikan terhadap kepuasan pelanggan semen Baturaja di Palembang.

$$
\begin{aligned}
& \mathrm{H}_{\mathrm{a}} \text { : Kualitas produk berpengaruh } \\
& \text { signifikan terhadap kepuasan } \\
& \text { pelanggan semen Baturaja di } \\
& \text { Palembang. }
\end{aligned}
$$


- Keputusan :

Jika $t_{\text {hitung }} \geq \mathrm{t}_{\text {tabel }}$ maka Ho ditolak

Jika $t_{\text {hitung }} \leq \mathrm{t}_{\text {tabel }}$ maka Ho diterima

Untuk menghitung $t$ tabel digunakan ketentuan sebagai berikut :

- $\alpha=0,05$

- $\mathrm{df}=$ (jumlah responden - bilangan konstanta) atau $(78-2=76)$

- $\mathrm{t}_{\text {tabel }}=1.665$ ( hasil dari tabel $\mathrm{t}$ (lampiran).

Hasil hipotesis Uji t dapat dilihat tabel sebagai berikut :

\section{Tabel 8}

\section{Hasil Uji t}

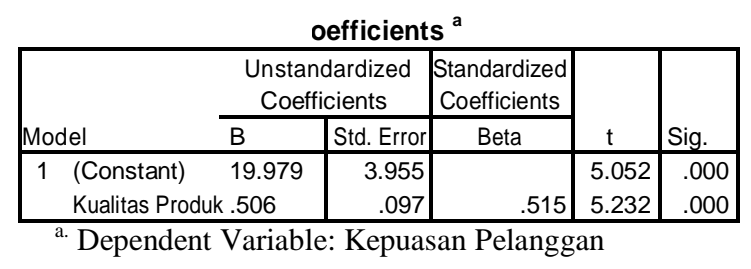

Sumber : Hasil Olahan Data SPSS 15.0

Dari tabel diatas dapat diketahui bahwa nilai $\mathrm{t}$ hitung sebesar $(5,232)$ dengan nilai signifikan adalah $(0,000)$ dan $t$ tabel $(1,665)$. Karena $t$ hitung $(5,232) \geq t$ tabel $(1,665)$ dan nilai signifikan $(0,000) \leq 0,05$. Hal tersebut menunjukkan bahwa $\mathrm{H}_{\mathrm{o}}$ ditolak dan $\mathrm{H}_{\mathrm{a}}$ diterima, maka Kualitas Produk berpengaruh signifikan terhadap Kepuasan Pelanggan semen Baturaja di Palembang.

\section{Pembahasan}

Penelitian dengan melibatkan sebanyak 78 responden, untuk memberikan informasi mengenai pengaruh variabel $\mathrm{X}$ yaitu kualitas produk terhadap variabel $Y$ kepuasan pelanggan. Berdasarkan hasil analisis deskriptif tentang karakteristik responden, di dapat bahwa dari 78 orang yang menjadi responden pada penelitian ini sebagian besarnya adalah laki-laki $(52 \%)$, dan sisanya (26\%) adalah perempuan, dan berdasarkan usia, diketahui bahwa yang paling banyak menjadi responden pada penelitian ini adalah responden dengan usia $31-40$ tahun (39\%), sisanya (21\%) merupakan responden dengan usia 41 - 50 tahun, dan $(18 \%)$ merupakan responden dengan usia 20 - 30 tahun. Sedangkan berdasarkan pendidikan terakhir responden jumlah yang paling banyak adalah responden lulusan S1 (32\%), kemudian responden lulusan diploma (27\%), dan responden lulusan SLTA (19\%). Kemudian dari hasil analisis deskriptif untuk jawaban responden tentang pernyataan pada kuesioner, didapat bahwa responden paling menyetujui menjawab Setuju (S) dan Sangat Setuju (SS) adalah pada pernyataan 1.4 , yaitu tentang daya tahan yang kuat, Artinya dimensi ini merupakan yang menjadi alasan utama dalam kepuasan pelanggan Semen Baturaja.

Hasil uji validitas menunjukkan bahwa semua pernyataan yang berada dikuesioner yang telah disebar dinyatakan valid, karena $\mathrm{r}_{\text {hitung }} \geq \mathrm{r}_{\text {tabel, }}$ dengan hasil $\mathrm{r}_{\text {tabel }}$ sebesar 0,222. Hasil uji reliabilitas menunjukkan semua koefisien reliabel $\geq$ 0,70, hal ini menunjukkan bahwa pernyataan dalam kuesioner reliabel.

Persamaan regresi yang diperoleh dari penelitian ini adalah $\mathrm{Y}=19,979+(0,506)$ $X$. Dari persamaan regresi tersebut diketahui bahwa parameter koefisien regresi variabel kualitas produk berpengaruh terhadap kepuasan pelanggan semen Baturaja di Palembang. Artinya setiap terjadi peningkatan variabel kualitas produk maka kepuasan pelanggan akan mengalami kenaikan.

Dalam upaya mengidentifikasi seberapa jauh hubungan dan pengaruh variabel independen terhadap dependennya, dilakukan uji korelasi dan determinasi dimana diperoleh besarnya nilai korelasi / hubungan $(\mathrm{R})$ yaitu sebesar $=0,515$ artinya koefisien korelasi menunjukkan bahwa hubungan antara Kualitas Produk terhadap Kepuasan Pelanggan berasumsi sedang yaitu sebesar 51,5\%. Setelah uji korelasi dilakukan uji determinasi. Uji determinasi dilakukan untuk melihat seberapa besar kontribusi variabel $\mathrm{X}$ terhadap variabel $\mathrm{Y}$, dimana diperoleh $\mathrm{R}$ 
Square (determinasi) sebesar 0,265 , yang mengandung pengertian bahwa pengaruh variabel bebas (Kualitas Produk) terhadap variabel terikat (Kepuasan Pelanggan) adalah sebesar $26,5 \%$, sedangkan sisanya yaitu $73,5 \%(100 \%$ - 26,5\%) dipengaruhi oleh variabel lain yang tidak diteliti dalam penelitian ini.

Selanjutnya untuk mengetahui signifikan tidaknya hasil penelitian dengan menghitung Diketahui dari uji hipotesis parsial menunjukkan angka thitung $_{\text {sebesar }}$ $(5,232)$ sig $(0,000)$ dan $\mathrm{t}$ tabel $(1,665)$. Karena $\mathrm{t}$ hitung $(5,232) \geq \mathrm{t}$ tabel $(1,665)$ dengan sig $(0,000) \leq 0,05$. Artinya bahwa variabel kualitas produk berpengaruh signifikan terhadap kepuasan pelanggan semen Baturaja di Palembang.

Hasil ini sejalan dengan penelitian yang dilakukan oleh Yetty Husnul Hayati dan Gracia Sekartaji [4], dengan judul "Pengaruh Kualitas produk Terhadap Kepuasan Konsumen di Restoran Bebek dan Ayam Goreng Pak Ndut Solo" yang mengungkapkan fakta bahwa kualitas produk berpengaruh terhadap kepuasan konsumen. Hal tersebut dapat dilihat pada tabel Correlation yang didapat sebesar $r_{x y}$ 0,710 , dan nilai $\mathrm{r}_{\text {tabel }}$ pada $d f 398$ adalah 0,098, maka dapat diartikan terdapat hubungan yang positif antara kualitas produk terhadap kepuasan konsumen. kemudian berdasarkan uji $\mathrm{t}$ menyatakan bahwa t hitung memiliki nilai yang lebih besar dari nilai t tabel yaitu 1,966>0,05 yang berarti terdapat hubungan yang signifikan antara variabel independen yaitu Kualitas Produk dari rumah makan Bebek dan Ayam Goreng Pak Ndut dengan Kepuasan Konsumen. Hasil penelitian ini juga didukung dengan penelitian terdahulu yang dilakukan Panzy Syaparilwadi dan Aditya Wardhana [15]. dengan judul Pengaruh Kualitas Produk Terhadap Kepuasan Pelanggan pada Perusahaan Konveksi Fazry. Yang menyatakan bahwa adanya tingkat korelasi yang sedang dan hubungan yang signifikan antara kualitas produk dengan kepuasan pelanggan. Sehingga, hasil penelitian ini menunjukkan bahwa secara parsial kualitas produk berpengaruh terhadap kepuasan pelanggan sebesar $58,9 \%$ dan sisanya sebesar $41,1 \%$ dipengaruhi oleh faktor lain yang tidak diteliti dalam penelitian ini.

Upaya selanjutnya dilaksanakan oleh PT. Semen Baturaja (Persero) Tbk dalam meningkatkan kepuasan pelanggan dalam rangka mewujudkan visi dan misi perusahaan tersebut diharapkan agar tidak hanya menggunakan dan menjalankan strategi penerapan kualitas produk saja tetapi harus mencakup seluruh komponen yang berkaitan dengan pemasaran dan mempunyai hubungan dengan kepuasan pelanggan. Sehingga laju pertumbuhan PT. Semen Baturaja (Persero) Tbk akan semakin cepat dan mampu bersaing dengan perusahaan lain yang bergerak dalam bidang yang sejenis.

\section{Penutup}

\section{Kesimpulan}

Berdasarkan dari analisis dan hasil penelitian yang telah dibahas sebelumnya, sesuai dengan tujuan dari penelitian ini yaitu untuk melihat pengaruh kualitas produk semen Baturaja terhadap kepuasan pelanggan, maka dapat disimpulkan hasil dari penelitian ini sebagai berikut :

1. Hasil persamaan regresi sederhana dengan Koefisien konstanta sebesar 19,979 menyatakan bahwa jika $\mathrm{X}$ adalah bernilai nol (0). Artinya adalah apabila Kualitas Produk bernilai nol (0), maka Kepuasan Pelanggan bernilai sebesar 19,979 dan Koefisien regresi untuk variabel Kualitas Produk sebesar 0,506. Artinya adalah menunjukkan bahwa setiap peningkatan variabel Kualitas Produk sebesar 1 kali maka akan menaikkan nilai Kepuasan Pelanggan sebesar 0,506 dengan asumsi variabel lain bernilai tetap.

2. Dari hasil koefisien korelasi terdapat hubungan yang cukup kuat / sedang dan positif antara variabel bebas (Kualitas Produk) terhadap variabel 
terikat (Kepuasan Pelanggan Semen Baturaja) dengan nilai korelasi / hubungan $(\mathrm{R})$ yaitu sebesar $=0,515$ atau $(51,5 \%)$.

3. Kemudian dari hasil analisis data pada tabel uji koefisien determinasi $\left(\mathrm{R}^{2}\right)$ terlihat bahwa $R$ Square adalah sebesar 0,265 , ini artinya pengaruh variabel bebas (Kualitas Produk) terhadap variabel terikat (Kepuasan Pelanggan) adalah sebesar 26,5\%, sedangkan sisanya yaitu $73,5 \%(100 \%-26,5 \%)$ dipengaruhi oleh variabel lain yang tidak diteliti dalam penelitian ini. Hal ini menunjukkan bahwa variabel kualitas produk mempunyai pengaruh yang cukup sedang terhadap kepuasan pelanggan sehingga perlu di lakukan penelitian dengan menggunakan variabel lain untuk memuaskan pelanggan seperti variabel kualitas pelayanan, harga, promosi, tempat dan lain-lain.

4. Dalam hasil pengujian hipotesis diketahui nilai $\mathrm{t}$ hitung sebesar $(5,232)$ $\operatorname{sig}(0,000)$ dan $t$ tabel $(1,665)$. Karena $t$ hitung $(5,232) \geq \mathrm{t}$ tabel $(1,665)$ dan nilai $\operatorname{sig}(0,000) \leq 0,05$. Hal tersebut menunjukkan bahwa $\mathrm{H}_{\mathrm{o}}$ ditolak dan $\mathrm{H}_{\mathrm{a}}$ diterima, maka Kualitas Produk berpengaruh signifikan terhadap Kepuasan Pelanggan Semen Baturaja di Palembang.

\section{Saran}

Berdasarkan analisis dan hasil penelitian tentang pengaruh kualitas produk terhadap kepuasan pelanggan Semen Baturaja di Palembang, maka dengan ini penulis memberikan masukan atau saran sebagai berikut :

1. Penulis memberikan saran dari hasil penelitian ini PT. Semen Baturaja (Persero) Tbk, diharapkan terus berupaya mempertahankan atau bahkan meningkatkan kualitas produk agar kepuasan pelanggan semakin bertambah, hal ini karena kepuasan pelanggan merupakan kunci perusahaan untuk membentuk loyalitas pelanggan.

2. Variabel yang digunakan dalam penelitian ini telah terbukti saling mempengaruhi satu sama lain, tetapi masih ada $73,5 \%$ dipengaruhi oleh variabel lain yang bukan menjadi sasaran dari penelitian ini. variabel lain yang dapat mempengaruhi kepuasan pelanggan semen baturaja bisa berupa kualitas layanan, harga, promosi, dan tempat.

3. Penulis menyarankan untuk penelitian selanjutnya dengan menggunakan variabel lain misalnya variabel harga, karena dari hasil wawancara penulis dengan konsumen diketahui bahwa harga produk semen baturaja lebih mahal dari produk semen yang lain, sehingga menyebabkan sebagian konsumen lebih memilih produk semen yang lebih murah.

\section{DAFTAR PUSTAKA}

Alma, Buchari. 2013. Manajemen Pemasaran dan Pemasaran Jasa. Bandung: Alfabeta.

Arikunto, Suharsimi. 2010. Prosedur Penelitian Suatu Pendekatan Praktik. Yogyakarta: Rineka Cipta.

Assauri, Sofjan. 2011. Manajemen Pemasaran. Jakarta: PT. RajaGrafindo Persada.

Hayati, Yetty Husnul \& Gracia Sekartaji. (2015). "Pengaruh Kualitas Produk Terhadap Kepuasan Konsumen di Restoran Bebek dan Ayam Goreng Pak Ndut Solo". Jurnal Ilmiah Manajemen Fakultas Ekonomi. Volume 1. No. 1. ISSN 2502-1400.

Kotler, Philip. 2010. Manajemen Pemasaran: Analisis, Perencanaan, Implementasi dan Kontrol, (terjemahan Hendra Teguh dan 
Ronny A. Rusli AK). Jakarta: PT. Ikrar Mandiriabadi.

Kotler, Philip and Gary Armstrong. 2012. Prinsip-Prinsip Pemasaran. Edisi 13. Jilid 1. Jakarta: Erlangga.

Kotler, Philip and Kevin Lane Keller. 2012. Marketing Manajemen 13. New Jersey: Pearson Prentice Hall, Inc.

Kusumawati, Andriani. (2014). "Pengaruh Kualitas Produk dan Kualitas Pelayanan terhadap Kepuasan Pelanggan dalam membentuk Loyalitas Pelanggan (Studi pada Pelanggan McDonald's MT.Haryono Malang)". Jurnal Administrasi Bisnis (JAB). Vol. 15, N0 1.

Nisfiana, Dewi Nurun. (2009). "Pengaruh Kualitas Produk terhadap Kepuasan Konsumen dalam Membeli Daging Sapi ( Studi pada konsumen depot daging Mubarokah, Mojokerto)". Jurnal Manajemen Pemasaran. Volume 1. No. 1.

Sudaryono. 2016. Manajemen Pemasaran Teori dan Implementasi. Yogyakarta: C.V Andi Offset.

Sunyoto, Danang. 2015. Manajemen Pemasaran Jasa. Yogyakarta: CAPS (Center for Akademic Publishing Service).

Sugiyono. 2013. Metode Penelitian Bisnis (Pendekatan Kuantitatif, Kualitatif, dan $R \& D$ ). Bandung: Alfabetha.

Tjiptono, F. 2014. Pemasaran Jasa Prinsip, Penerapan, dan Penelitian. Yogyakarta: C.V Andi Offset.

Tjiptono, Fandy. 2015. Strategi Pemasaran. Edisi 4. Yogyakarta: C.V Andi Offse
Wardhana, Aditya dan Panzy Syaparilwadi. (2015). "Pengaruh Kualitas Produk terhadap Kepuasan Pelanggan pada Perusahaan Konveksi Fazry". Jurnal Administrasi Bisnis. Vol. 1. No. 1.

Widjoyo, Iksan Ongkos, Leonid Julivan Rumambi, \& Yohanes Sondang Kunto. (2013). “Analisis Pengaruh Kualitas Layanan Terhadap Kepuasan Konsumen pada Layanan Drive Thru McDonald's Basuki Rahmat di Surabaya". Jurnal Manajemen Pemasaran. Vol. 1. No. 1.

http://www.kemenprin.go.id/pasokansemen-nasional diakses pada hari: Senin, 05 Desember 2016.

http://www.semenbaturaja.co.id diakses pada hari: Kamis, 01 Desember 2016.

http://www.indocement.co.id diakses pada hari :senin, 05 Desember 2016

http://www.holcim.co.id diakses pada hari: Senin, 05 Desember 2016.

http://www.semenpadang.co.id diakses pada hari: Senin, 05 Desember 2016.

http://www.bosowa.co.id/grupusaha/page/ semen diakses pada hari : Senin, 05 Desember 2016.

http://www.sementonasa.co.id/profilebrief. php diakses pada hari : Senin, 05 Desember 2016. 